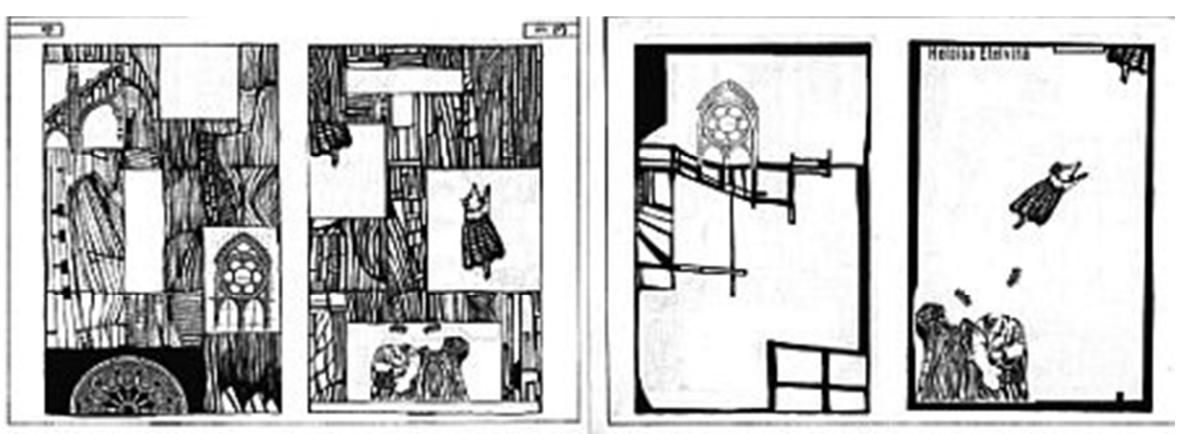

Ilustração Eloisa Ethelvina

\title{
Alice Bicalho
}

Alice Bicalho nasceu em Belo Horizonte e morou em alguns outros lugares, quando escreve deixa de ter data e local de nascimento e vive um texto. Sem nunca ter certeza de conseguir alcançar outros lugares literários vai por aí, tentando, escrevendo.

Colocando as peças no tabuleiro.

Qual será o não jogo desta vez?

O Rapaz, antes de todo movimento, reafirma: "Eu não sei jogar, eu não quero jogar, eu não jogo" e mexe o peão.

A mocinha já admitiu seu papel. Mexe peões, faz linhas retas com torres, pula e se esquiva com cavalos, mas não toca em sua rainha.

A rainha branca permanece também imóvel, dona de si, atrás de seus movimentos potenciais dados pelo poder de saber dizer "não sei".

Agora examinamos o xadrez. Não é mais este o jogo que conta, mas outros, anteriores.

"Aquela jogada já está morta e enterrada."

Mas permanecem seu pertences, apetrechos, gritos e abusos escondidos num canto qualquer.

"Este jogo é feito em silêncio. Agora irei comer seu primeiro deslize com um simples operário".

Ela sempre, sempre se entrega.

Eles não querem jogar e jogam.

Tudo isto parece muito perigoso.

Agora foram para o quarto à beira do despenhadeiro.

Lá reina o tédio que pode ir para todas as direções, mas em um 
quadrado branco por vez.

Para um lado.

Se algo negro se aproxima, volta ao mesmo lugar: jogo de soma zero.

Não tem ataque.

Imensa neblina de defesas.

As peças dela são as pretas. Diz a lenda: mais chances de ganhar

Se jogasse com alguém...

Do outro lado do tabuleiro sobre o colchão duro de casal, joga não jogando um imenso abismo: vazio de vontades.

Ela olha para o fundo daquele abismo.

Não, de novo.

Basta um sonho, apenas um pesadelo, talvez.

Não será preciso que ninguém se jogue para que o outro perceba e diga "Sua beleza..."

Solta um grito enorme que assusta por não ser esta sua

natureza de sofrer ou amar.

Uma força qualquer levanta seu rosto. Há um homem ao seu lado. "Quem será este homem?"

Não importa, no momento, quem ele é, mas sua voz que diz: "O ABISMO É O MESMO. Mantenha o olhar no horizonte".

Acorda e o abismo continua no mesmo lugar.

Um peão anda pra trás quando:

"Eu gostaria de ter te levado ao menos ao ponto"

Mas não levou.

Não foi sequer à porta de

Não fez nenhum pedido, nenhuma proposta.

O Rei voltou ao lugar de origem quando:

"Eu queria apenas te levar ao ponto porque estava preocupado com os perigos da região".

A rainha preta começa a aparecer em risada quando:

"Os perigos da região são jogos de fato. Não me metem medo. Tenho gamas de movimento e desejo."

O Rei branco se esconde atrás da rainha branca que mora uns andares acima porque:

A RAINHA BRANCA TEM PÊNIS E ÂNUS.

Se o jogo acaba quando um rei morre, vemos a cena:

o abismo contra si mesmo, contra a mocinha e a favor de sua enorme fúria: estar sempre parado e cada vez mais profundo. 
Txt: Leituras Transdisciplinares de Telas e Textos, Belo Horizonte, v.2, n.4, p.104-106, 2006

Um jogo nunca termina quando nunca começa. Ela sente sua força transformadora, mas sugada... está sugada.

Será tarde demais para começar, ou

qual rei irá se suicidar?

Não há xeque

mate 